TILTAI, 2016, 2, 125-142, ISSN 1392-3137 (Print), ISSN 2351-6569 (Online)

\title{
JŪRINIŲ PROFESIJŲ SPECIALISTŲ KARJEROS PROJEKTAVIMO VEIKSNIAI
}

\author{
Diana Saveikienè \\ Klaipedos universitetas
}

\begin{abstract}
Anotacija
Jūrinių profesijų specialistų darbo rinka pasižymi ypatingais darbo vietų ir teisinio reglamentavimo pokyčiais. Tai skatina atlikti jūrinių profesijų specialistų karjeros projektavimo ir igyvendinimo veiksnių tyrimus. Šiame straipsnyje siekiama identifikuoti jūrinès profesijos specialistų tolesnès karjeros projektavimo ir igyvendinimo veiksnius. Teorinejje straipsnio dalyje nagrinėjami profesijos pasirinkimo klausimai, karjeros, karjeros projektavimo sampratos, išanalizuotas jūrinių profesijų specialistų rengimo tarptautinis ir nacionalinis reglamentavimas. Empirinejje dalyje, atlikus kiekybinį tyrimą, nustatyti jūrinių profesijų specialistų karjeros siekį skatinantys ir slopinantys veiksniai. Praktinis tyrimo reikšmingumas sietinas su jūrinių profesijų specialistų karjeros projektavimo kompetencijų ugdymo realizavimu.

PAGRINDINIAI ŽODŽIAI: jūrinių profesijų specialistai, profesija, karjera, jūrinė karjera, karjeros projektavimas.
\end{abstract}

\begin{abstract}
The labour market of maritime professionals is characterized by extreme changes in the workplace and legal regulations. This urges to conduct the research of factors of career development and implementation of maritime professionals. The aim of this article is to identify the factors of design and implementation of further career of marine professionals The theoretical part of the article deals with the choice of profession, career, career design concept, and analyses the international and national regulation of maritime professionals training. Educational and vocational institutions have not only to ensure training of skilled professionals but also the systematic and streamlined career education. Having conducted a quantitative research, and expert surveys factors that promote and inhibit the pursuit of maritime professions career were set in the empirical part. The practical significance of the research should be related to the realization of career development competencies of maritime professionals.
\end{abstract}

KEY WORDS: Maritime professionals, Profession, Career, Maritime career, Career design.

DOI: http://dx.doi.org/10.15181/tbb.v74i2.1371

\section{Ivadas}

Jūrinių profesijų specialistų darbo rinka pasižymi ypatingais darbo vietų ir teisinio reglamentavimo pokyčiais. Profesinis informavimas ir konsultavimas bei individo ugdymas karjerai yra svarbūs švietimo sistemos uždaviniai, tai reikšmingi mokymosi visą gyvenimą strategijos elementai, esantys ir dokumento „Europos Komisija: Mokymosi visą gyvenimą memorandumas“ (2001) prioritetas. Pasirinkta tyrimo problema atitinka „Mokymosi visą gyvenimą užtikrinimo strategiją“, kuri aktualizuoja idejją, keliamą komunikate „Suaugusiųjų mokymasis“, - mokytis 
niekada nevèlu. Problemos aktualumą pagrindžia LR švietimo ir mokslo ministro, LR socialinès apsaugos ir darbo ministro įsakymas „Dèl profesinio orientavimo vykdymo tvarkos aprašo patvirtinimo“ (2012), kuriame teigiama, kad profesinio orientavimo tikslas - padèti asmenims sąmoningai rinktis jiems tinkamas švietimo ir užimtumo galimybes, sudaryti sąlygas ịgyti karjeros kompetencijų, aktyviai kurti savo karjerą. Pasirinkta tyrimo tema atitinka ir „Strategijos „Europa 2020“ programą“, kurioje numatomos priemonès, kaip gerinti visų pakopų išsilavinimo prieinamumą. Ugdymosi karjerai perspektyvos ir galimybės išryškëja ir „Lietuvos pažangos strategijoje „Lietuva 2030“, kuri grindžiama darnaus vystymosi principais. Moksliškai tirti pasirinktą problemą skatina „Valstybinè švietimo 2013-2022 m. strategija“, raginanti operatyviau reaguoti ị pokyčius darbo rinkoje, gebèti savarankiškai valdyti karjerą, rinktis perspektyvesnes karjeros kryptis. Jūrininkų karjeros projektavimo ir ígyvendinimo problemos aktualumą pabrěžia šių specialistų rengimą, diplomavimą, laive vykdomas funkcijas reglamentuojantys tarptautiniai bei nacionaliniai teisės aktai. Nuo $2014 \mathrm{~m}$. pradžios turimi jūrinių profesijų specialistų dokumentai keičiami ị dokumentus, kurie atitinka „Tarptautinès konvencijos dèl jūrininkų rengimo, atestavimo ir budejjimo normatyvų“ (toliau - STCW konvencija) su 2010 m. Manilos pakeitimais reikalavimus Lietuvos Respublikos susisiekimo ministro nustatyta tvarka. Nuo 2016 metų išduodami nauji dokumentai pagal Manilos pataisų reikalavimus.

Karjera - tai daugiadalykis mokslinių tyrimų objektas, šia tema daugiausia darbų publikuoja edukologijos, psichologijos, sociologijos ir kitų socialinių mokslų atstovai. R. Laužackas (2005) parengè profesinio rengimo metodologiją, sudarẻ profesinio rengimo terminų aiškinamajj žodyną, L. Jovaiša sukūrè originalią profesinio orientavimo ir konsultavimo sistemą, analizavo profesinio orientavimo ir konsultavimo klausimus psichologiniu bei edukologiniu požiūriais, paklojo teorinius profesinio orientavimo pamatus $(2007,2009,2011,2012)$. M. Barkauskaitė (2007) analizavo profesinị konsultavimą ir orientavimą šiuolaikinio profesinio rengimo kontekste; N. Petkevičiūtè (2006) tyrè karjeros valdymo perspektyvas; apie edukologines prielaidas rašė E. Danilevičius (2008), D. Augienè (2009); karjeros sampratos konstravimą Lietuvoje nagrinejjo V. Rosinaite (2010); karjeros projektavimo ir profesinio rengimo sąveiką tyrè V. Tūtlys (2013). A. Sokolova ir V. Stanišauskienė (2007) analizavo profesinio orientavimo sistemos Lietuvoje teorines ir politines prielaidas; pašaukimo profesijai ir profesijos rinkimosi klausimais rašè I. Urbanavičiūtė (2010), V. Kavaliauskienė (2011); T. R. Jovaiša (2012). Karjeros projektavimo konsultavimo ir paslaugų nūdienos aktualijas nagrinèjo R. Adamonienè (2007), K. Pukelis $(2007,2009,2012)$, K. Pukelis, L. Navickienè (2010, 2011), J. Arnold (2005, 2011), R. D. Sultana (2012), P. Plant (2012), 
L. Navickienè (2012), J. J. Ruppert, B. J. Ertelt (2013), F. Eder, G. Hörn, J. Frübing (2013).

Straipsnio objektas - jūrinès profesijos specialistų karjeros projektavimas ir igyvendinimo veiksnių santykinè svarba.

Straipsnio tikslas: ịvertinti jūrinès profesijos specialistų tolesnès karjeros projektavimo ir iggvendinimo veiksnius.

\section{Profesijos ịgijimas - karjeros pradžia}

Gyventi - tai reikšti savo prigimtį, iggyti patirties, skleisti tiesą ir šviesą, būti laimingam bendraujant su žmonėmis, atliekant mėgstamą darbą. Sėkmingas darbas ir bendravimas garantuoja dvasinę pusiausvyrą (Jovaiša, 2009a). Europoje vyraujančios humanistinès nuostatos stiprina ịsitikinimą, kad kiekvienas asmuo, žengiantis savo asmenybės kūrimo ir tobulinimo keliu, gali pasiekti tikslą (Tijūnèlienė, Kavaliauskienè, 2008, p. 41). Labai aktualiai šiame kontekste skamba L. Jovaišos žodžiai, kad lemtingas sėkmingo gyvenimo dalykas yra profesijos pasirinkimas ir vertingas darbas. Tinkamai pasirinkta profesija, mėgstamas darbas, karjera - svarbūs kiekvieno žmogaus gyvenime, todèl profesijos rinkimasis yra neišvengiamas ir tampa žmogaus būties tvarkymo veiksniu (Jovaiša, 2011). Karjerą galima pradèti planuoti tik apsisprendus dèl profesijos, t. y. pasirinkus profesiją, nes kiekvieną karjeros planą lemia konkrečios profesijos prigimtis (Pukelis, 2007, p. 13).

V. Kavaliauskienės (2011) teigimu, kalbant apie profesijos esmę galimas objektyvusis ir subjektyvusis, arba socialinis ir individualusis aiškinimai. Objektyviaja prasme profesija yra socialinis reiškinys, socialinès veiklos rūšis. Šioje veikloje žmogus pritaiko savo žinias, igūdžius ir gabumus, visuomenès labui dirbdamas tam tikroje gamybinès ar negamybinès veiklos srityje. Tai kvalifikuota, socialiai prasminga žmogaus veikla tam tikroje visuomenès gyvenimo srityje. Objektyvusis profesijos aspektas ir jo turinys siejami su profesinès veiklos struktūra, profesijos keliamais reikalavimais, veiklos sąlygomis, aplinkybėmis. Subjektyvusis profesijos aspektas siejamas su pačiu žmogumi - šių funkcijų atlikèju, jų turinio skleidejju, su vidine, nematoma profesinès veiklos puse, individo savimone, pasireiškiančia savęs pažinimu, teigiamu santykiu su profesija, tinkamumo šiai profesijai išgyvenimu ir siekiu ją realizuoti dirbant toje srityje (Kavaliauskienè, 2011, p. 46). Dauguma tyrejjų pritaria, kad esminiai darbo pagal pašaukimą bruožai - džiaugsmas ir gyvenimo jèga, sudaranti žmogaus dvasios gyvenimo esmę. Taigi emocinis asmens santykis netgi laikytinas pagrindiniu pašaukimo komponentu, emocinis nusiteikimas profesijos atžvilgiu susijęs su gyvenimo prasmès klausimu ir teigiamomis profesinèmis nuostatomis. 


\section{Karjeros projektavimas - asmenybės sėkmingos saviraiškos prielaida}

Karjera, kaip teigia N. Petkevičiūtè, daugeliui žmonių yra pirminis veiksnys, apibūdinantis gyvenimo kokybę ir patenkinantis beveik visus žmogaus poreikius, ji tampa viso žmogaus gyvenimo palydove, svarbia gyvenimo dalimi, kuria reikètų rūpintis visą asmens gyvenimą. Autorès teigimu, mokslinèje literatūroje ji gali turèti keturias pagrindines reikšmes: karjera kaip pasiekimai (taip ji suvokiama daugiausia darbo aplinkoje); karjera kaip profesija (ji gali būti daugiau ar mažiau prestižinè); karjera kaip nuosekli nuolatinio darbo tąsa: kiekvienas dirbantis žmogus turi savo darbo istoriją, karjerą; karjera kaip viso gyvenimo įvairiu vaidmenu patirties seka (Petkevičiūtè, 2006, p. 16).

Užsienio autorių N. Dries, R. Pepermans, O. Carlier (2008, p. 255), H. M. L. Yaxley (2012, p. 400; 2013, p. 158), C. J. Vinkenburg, T. Weber (2012, p. 594) nuomone, klasikiniu laikomas H. L. Wilensky (1961, p. 523) karjeros apibrèžimas: „Karjera - tai eilè pagal prestižą hierarchijos principu išrikiuotu giminingų darbų, kurių individas nuosekliai (arba ne visai nuosekliai) siekia." Belgijos mokslininkès V. Germeijs ir K. Verschueren tyrè karjeros sprendimų prièmimo problemą ir išskyrè šešias profesijos pasirinkimo užduotis, integravusios ị visumą objektyvius ir subjektyvius veiksnius:

- Orientacija: poreikio priimti sprendimą suvokimas ir motyvacija priimti tokị sprendimą.

- Savęs tyrinejjimas: informacijos apie save rinkimas.

- Aplinkos analize: bendros informacijos apie aplinką ir karjeros alternatyvas rinkimas.

- Aplinkos elementu analizé: detalios informacijos apie keletą pasirinktų karjeros alternatyvų rinkimas.

- Sprendimas: alternatyvos pasirinkimo pažanga.

- Isipareigojimas: pasitikejjimo ir įsipareigojimo stiprumas pasirinktos konkrečios karjeros alternatyvos atveju (Germeijs, Verschueren, 2007, p. 225).

G. Kalvaitienès nuomone, karjera žmogaus gyvenime vaidina svarbų vaidmenị, nes žmogus pats ją kuria, vertina, ne tik nuo tada, kai pasirinko profesiją, bet visą darbingą gyvenimo dali, nes karjera yra nuolatinio asmenybės tobulèjimo ir profesinès saviraiškos procesas. Žmogus plètoja savo karjerą tiek individualioje, tiek socialinèje srityje, todèl ji priklauso tiek nuo individualių pastangų, asmeniniu gebėjimų, tiek nuo aplinkos, kuri jị supa ir veikia (Kalvaitienè, 2010, p. 62).

Apibendrinant galima teigti, kad karjera - ịvairių socialiai reikšmingų žmogaus vaidmenų seka, nulemta darbo, mokymosi, saviraiškos ir laisvalaikio veiklų bei apimanti asmens profesini gyvenimą, darbo vietas, pareigas ir pasiekimus. Ak- 
centuojant karjeros sėkmingumą, sėkmingą karjerą šiuo metu sunku ịsivaizduoti kitaip nei paties žmogaus planuojamą, organizuojamą ir plètojamą procesą.

\section{Jūrinių profesijų specialistų karjeros projektavimo ir igyvendinimo veiksnių empirinio tyrimo rezultatai}

Mokslinès literatūros analizė atskleidè, kad profesijos esmė, jos reikšmė žmogaus gyvenime, rinkimosi veiksniai ir karjeros projektavimas nagrinèti tiek teoriniu, tiek empiriniu aspektais, sukurtas jūrinių profesijų studentų profesinės karjeros planavimo mokẻjimų ugdymo modelis (Kalvaitienè, 2012), tačiau jau dirbančiu jjuriniu profesiju specialistu karjeros projektavimo ir igyvendinimo veiksniai- mažai tyrinèta sritis.

Pasirinkto tyrimo mokslinè problema formuluojama šiais klausimais:

1. Koks galètų būti jūrinių profesijų specialistų karjeros projektavimo ir įgyvendinimo veiksnių bazinis karjeros siekimo modelis?

2. Kokie realūs jūrinių profesijų specialistų karjeros projektavimo ir įgyvendinimo veiksniai veikia gyvenimo tikrovejje?

Išsikelti trys uždaviniai: atskleisti jūrinių profesijų specialistų karjeros projektavimo ir igyvendinimo veiksnių teorinị pagrindą, išryškinti, kokias prielaidas Lietuvos jūrininkų rengimo ir diplomavimo sistema, teisinè bazè sudaro jūrinès profesijos specialistų karjeros planavimui ir ịgyvendinimui, nustatyti jūrinės profesijos specialistų karjeros projektavimo ir igyvendinimo veiksnius.

Anketos klausimų klasifikavimas, atsižvelgiant ị tyrimo tikslą ir uždavinius: socialinè demografinè respondentų charakteristika, profesijos pasirinkimui poveikị darę veiksniai, karjeros poreikio identifikavimas ir ji formuojantys veiksniai, karjeros galimybių vertinimas, informacinès bazès pakankamumas. Atliekant kiekybinį tyrimą gautiems duomenims sisteminti ir analizuoti taikyti ịvairūs statistinès analizès metodai. Pirmiausia taikyti aprašomosios statistikos metodai: skaičiuojamas procentinis dažnis, mediana, vidurkis ir moda. Juos taikant apskaičiuotos įvairių kintamųjų skaitinès charakteristikos.

Epistimologinès tyrimo prielaidos. Pragmatizmo filosofijos nuostata, kad individualiojo pažinimo pagrindas - asmens sąveika su dinamiška, nuolat besikeičiančia aplinka. Šioje filosofijoje kertiniu dalyku skelbiama patirtis, kuri yra svarbiausia ir lemianti suvokiant pasauli bei planuojant ateitị. Šiomis mintimis remtasi empiriniame tyrime, siekiant nustatyti, ar jūrinių profesijų specialistai moka spręsti realias problemas, su kuriomis susiduria siekdami tolesnès karjeros, ar gali sèkmingai ją plètoti.

Socialinio konstruktyvizmo nuostata, kad tikrovès pažinimo ir mąstymo konstravimo procesas yra aktyvus, dinamiškas, tęstinis; realaus pasaulio pažinimo pro- 
cese konstruktyvus mąstymas padeda ne tik pažinti, bet ir keisti ugdymo tikrovę, igytas žinias taikyti įvairiose situacijose, lavinant aukštesnio lygmens mąstymo gebëjimus, skatinant aktyvaus mokymosi procesus turimų žinių ir patirties pagrindu. Savo kasdienėje veikloje (socialinė praktika) žmonės kuria ir perkuria realybės versijas. M. Savickas (2005) teigia, kad profesinès veiklos interesai ir jų matavimas yra socialiai sukonstruoti, kad karjera kuriama sąveikaujant dviem kintamiesiems - asmenybei ir visuomenei. Jūrinès profesijos specialistų karjeros siekimo būdus nustato jūrininkų rengimo ir diplomavimo sistema, todèl aktualus jų gebejjimas siekti tolesnès karjeros, atsižvelgiant ị reglamentuotus reikalavimus ir asmenines nuostatas. Šios idejjos tiko empiriniu tyrimu nustatant, ar aktuali jūrinių profesijų specialistams mokymosi visą gyvenimą idejja ir gebëjimas pasinaudoti galimybėmis kelti kvalifikaciją bei siekti karjeros.

Tyrimo imčiai sudaryti panaudotas netikimybinès tikslinės atrankos metodas: atrinkti kvalifikacijos kèlimo kursuose planuojantys dalyvauti jūrinių profesijų specialistai, igiję specialybes pagal Jūrų laivavedybos arba Laivų energetinių įrenginių eksploatavimo studijų programas Klaipėdos universiteto Jūrų technikos fakultete arba Lietuvos aukštojoje jūreivystès mokykloje. Tyrime apklausti 137 respondentai. Empirinis tyrimas, taikant kiekybinę tyrimų metodologiją ir anketinę apklausą, atliktas $2014 \mathrm{~m}$. kovo - balandžio mèn.

\section{Tyrimo rezultatų apžvalga}

Tyrime dalyvavusių respondentų amžiaus analizė atskleidè, kad vidutinis respondentų imties amžius - 39 metai. Kaip rodo respondentų pasiskirstymas pagal mokymosi įstaigą, kurioje jiems teko studijuoti, didesnè dalis respondentų studijavo ne vienoje, o keliose jūrinį išsilavinimą teikiančiose mokymo institucijose. $25,4 \%$ respondentų baigè studijas Laivininkų mokykloje ir ịgijo vidurinị profesinị išsilavinimą (žr. 1 pav.). Kaip rodo statistiškai patikimas koreliacinis ryšys, baigusieji Laivininkų mokyklą dažniau nurodè, kad baigė ir Lietuvos aukštają jūreivystės mokyklą. Tai natūralu, nes Laivininkų mokyklos užbaigimas ir jūrinès profesijos ịgijimas suteikia papildomą balą stojant ị Lietuvos aukštają jūreivystès mokyklą, kur vykdomos jūrinių studijų programos. Pritaikius $\chi^{2}$ metodą, nustatyta, kad statistiškai reikšmingai skiriasi respondentų atsakymai tarp mokymosi Laivininkų mokykloje ir respondento amžiaus $(p=0,045<0,05)$. Tyrimu nustatyta, kad visi respondentai, nurodę, kad studijavo Laivininkų mokykloje, yra jaunesni nei vidutinis imties respondento amžius, t. y. iki 39 metų. 


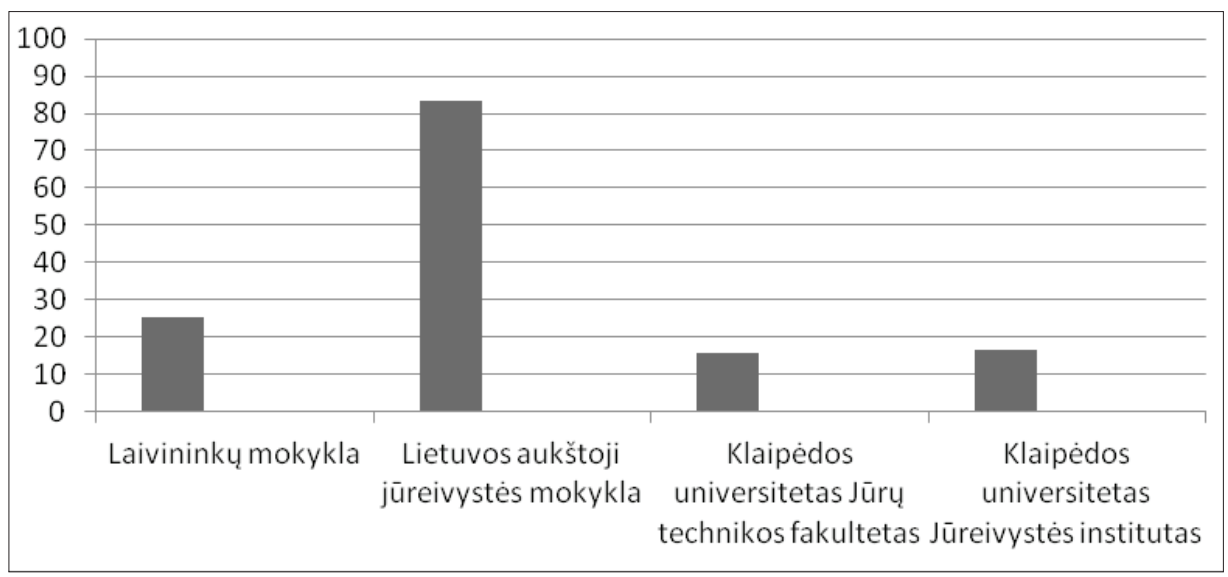

1 pav. Respondentų pasiskirstymas pagal mokymo įstaigą

83,3 \% respondentų studijavo Lietuvos aukštojoje jūreivystės mokykloje. Tai didžiausia apklaustų jūrininkų dalis. Tai galima patvirtinti tuo, kad šioje mokymo įstaigoje suteikiamas ne tik profesinio bakalauro diplomas, studijų metu jauni žmonès sukaupia būtiną plaukiojimo stažą, todèl užbaigę studijas ir išlaikę egzaminus ígyja jūrininko pažymėjimą, suteikiantị teisę įsidarbinti laivuose. 15,9\% apklaustų jūrininkų nurodė, kad yra baigę studijas Klaipėdos universiteto Jūrų technikos fakultete, tačiau reikia akcentuoti, kad jūrininkai, baigę studijas Laivininkų mokykloje, mažiau kartų nurode், kad pasirinko universitetines jūrinès pakraipos studijas (žr. 1 pav.). 16,7 \% apklaustų jūrininkų teigè, kad baigè studijas Klaipèdos universiteto Jūreivystès institute.

Kaip teigia 82,5 \% apklaustų jūrininkų, profesijos pasirinkima lèmė šie veiksniai: respondentas norèjo patenkinti savo interesus; jūrinè profesija atitiko jo pomėgius; jūrininko profesija padeda atskleisti charakterio bruožus. Tik 17,5 \% visų apklaustụjų profesiją pasirinko ne dèl minėtų priežasčių. Tyrimu nustatyta, kad 77,0 \% respondentų iki 39 metų (vidutinio imties respondentų amžiaus) nurodè, jog jūrinę profesiją pasirinko, norėdami patenkinti savo interesus ir poreikius, siekė atskleisti savo charakterio bruožus. Analizuojant profesijos pasirinkimo galimybes, kaip giminès tradicijų tąsą, nustatyta, kad 56,9\% respondentų teigè nežiną, ar taip iš tikrujų yra, tik beveik ketvirtadalis respondentų teigè, kad profesijos pasirinkimą lèmé giminès puoselèjamos jūrinès tradicijos (žr. 2 pav.). Daugiau nei pusè respondentų $(65,7 \%)$ nurodè, kad pasirinkti jūrinę profesiją paskatino šios profesijos autoritetas. Pritaikius $\chi^{2}$ metodą, nustatyta, kad statistiškai reikšmingi skirtumai atsakymuose nustatyti atsižvelgiant ị respondentų amžių $(p=0,000<0,05)$. Be to, nustatyta, kad statistiškai reikšmingai skiriasi respondentų atsakymai apie jūrinès profesijos pasirinkimą kaip giminès tradicijų tąsą $(p=0,029<0,05)$. Tyrimu nusta- 
tyta, kad $50 \%$ vyresnių nei 39 metų respondentų nurodė, jog profesiją pasirinko nemąstydami apie giminès tradicijų tęsimą.

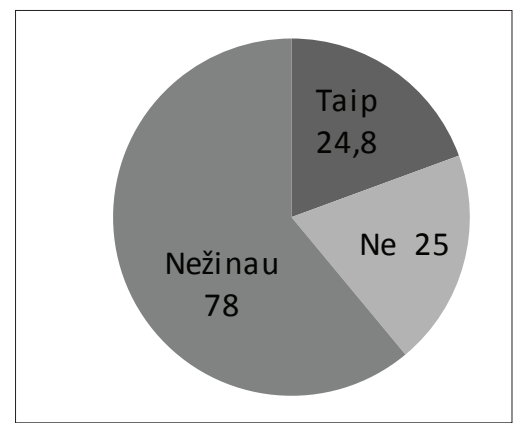

a)

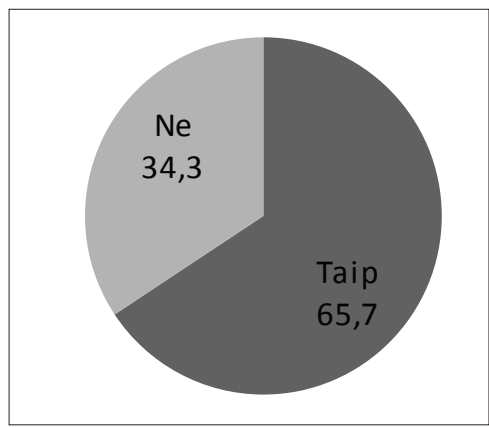

b)

2 pav. Jūrinès profesijos pasirinkimo priežastys:

a) giminès jūrinès tradicijos; b) jūrinès profesijos autoritetas

Analizuojant respondentų pasitenkinimą pasirinkta jūrininko profesija, nustatyta, kad visi tyrime dalyvavę respondentai yra patenkinti atliekamu darbu. Apibendrinant galima teigti, kad pagrindinis veiksnys, tureję̧s įtakos profesijos pasirinkimui, yra psichologinio pobūdžio, susijęs su saviraiška, o poreikis pratęsti giminès ar šeimos tradicijas būdingesnis jaunesnių nei vidutinis amžius respondentų daliai.

Renkant duomenis apie igytą jūrinị laipsni, nustatyta, kad konkretų jūrinị laipsnį turi 66,2 \% respondentų. Nustatyta, kad tyrime dalyvavo visų jūrinių laipsnių atstovai. Mažiausiai - aukščiausios kvalifikacinès kategorijos jūrinių laipsnio atstovų, bet tai natūralu ir atitinka jūrinès darbo rinkos tendencijas. Kaip parodè respondentų profesinių ateities planų jūrinio laipsnio keitimo požiūriu duomenų analizè, didžioji dalis respondentų $(29,0 \%)$ ketina siekti vyriausiojo mechaniko laivų, kurių variklių galia $-750 \mathrm{~kW}$ ir daugiau, bet mažiau nei $3000 \mathrm{~kW}$, jūrinio laipsnio. Penktadalis respondentų ketina siekti vyriausiojo mechaniko laivų, kurių variklių galia $-3000 \mathrm{~kW}$ ir daugiau, jūrinio laipsnio. Analizuojant atsakymus ị klausimą apie ateityje siekiamą igyti jūrinị laipsnị, akivaizdu, kad mechanikų specialybė tarp šiuo metu dirbančiu jūrininkų yra populiari. Pritaikius Mann-Whitney testą, nustatyta, kad statistiškai reikšmingai skiriasi respondentų atsakymai ị klausimus apie igytą ir planuojamą ịgyti jūrinị laipsnị. Toliau pateikiami statistiškai reikšmingi tyrimu nustatyti skirtumai tarp grupių: jūrininkai, šiuo metu turintys budinčio kapitono padèjèjo laivų, kurių BT - 3000 ir daugiau, laipsnị, 
linkę siekti vyresniojo kapitono padèjëjo laivų, kurių BT - 3000 ir daugiau, jūrinio laipsnio $(p=0,000<0,05)$; respondentai, šiuo metu turintys vyresniojo kapitono padèjejo laivų, kurių BT - 3000 ir daugiau, jūrinị laipsnị, ketina siekti kapitono laivų, kurių BT -3000 ir daugiau, jūrinio laipsnio $(p=0,018<0,05)$; respondentai, kurie dabar turi igiję laivo denio tarnybos jūreivio jürinị laipsni, ateityje planuoja siekti vyresniojo kapitono padejejejo laivų, kurių BT - 3000 ir daugiau, jūrinio laipsnio $(p=0,000<0,05)$; radijo operatoriaus jūrini laipsni turintys respondentai aukštesnio jūrinio laipsnio siekti neketina $(p=0,000<0,05)$; respondentai, igiję antrojo mechaniko laivų, kurių variklių galia $-750 \mathrm{~kW}$ ir daugiau, bet mažiau negu $3000 \mathrm{~kW}$,jūrinįlaipsnįplanuojaịgytivyriausiojomechanikolaivų, kuriųvarikliųgalia$750 \mathrm{~kW}$ ir daugiau, bet mažiau nei $3000 \mathrm{~kW}$, jūrinį laipsni $(p=0,030<0,05)$; respondentai, turintieji laivų mašinų skyriaus motoristo jūrinị laipsnị, ateityje planuoja siekti vyriausiojo mechaniko laivų, kurių variklių galia - daugiau nei $3000 \mathrm{~kW}$, jūrinio laipsnio $(p=0,000<0,05)$.

Tokios tendencijos rodo, kad ịgyjant jūrinius laipsnius egzistuoja aiški hierarchinio tipo karjeros planavimo sistema. Dažniausiai ji yra nuosekli, pavyzdžiui, nuo budinčio kapitono padejjèjo iki vyriausiojo kapitono padèjèjo, vèliau - kapitono jūrinio laipsnio. Tyrimu nustatyta, kad laivų mašinų skyriaus darbuotojai norètų siekti keliais laipsniais aukštesnio jūrinio laipsnio. Pritaikius $\chi^{2}$ metodą, statistiškai reikšmingų jūrinio laipsnio ịgijimo planų atsakymų skirtumų skirtingose amžiaus grupèse nenustatyta.

Analizuojant, kodèl respondentai pasirinko jūrinę profesiją ir dirba šị darbą, nustatyta, kad didžiausią poveikị daro veiksnys, kad jūrininko darbas atitinka respondentų gyvenimo stilių (žr. 3 pav.). Taigi vienas pagrindinių jūrininko karjerą formuojančių veiksnių yra jo asmeninis gyvenimo stilius. Net devyni dešimtadaliai respondentų teigè, kad dirbant jūriniame sektoriuje būtina nuolat siekti aukštesnio išsilavinimo, jeigu planuojama siekti karjeros, tai reiškia, kad antras pagal poveikio stiprumą yra išsilavinimo veiksnys, lemiantis galimybę siekti karjeros (žr. 3 pav.). 86,1 \% respondentų teigè, kad jürininko karjeros siekị stipriai veikia ir tai, kad dirbant jūrininku yra galimybė suderinti šeimos ir profesini gyvenimą, be to, jūrininko profesija ir karjeros siekis suteikia pakankamas socialines garantijas. Pagal poveikio stiprumą atlyginimo veiksnys siekti karjeros yra tik septintas. Išanalizavus, kaip jūrininkai siekia karjeros, nustatyta, kad visi be išimties respondentai ịvardijo 7 pagrindinius karjeros siekimo būdus, iš kurių galima sudaryti bazinị karjeros siekimo modeli:

1) studijos aukštojoje mokykloje;

2) įvairių kursų, susijusių su profesiniais reikalavimais, lankymas;

3) laivavedžiams ir laivų mechanikams skirtų konsultacijų lankymas; 
4) domejjimasis perspektyviausias karjeros galimybes sudarančiais darbdaviais;

5) asmeninès pastangos, siekiant tapti aukštos kvalifikacijos specialistu;

6) asmeninès pastangos turèti pakankamai žinių, kad galima būtų užsitikrinti profesinès veiklos sèkmę;

7) užsienio kalbų mokymasis.

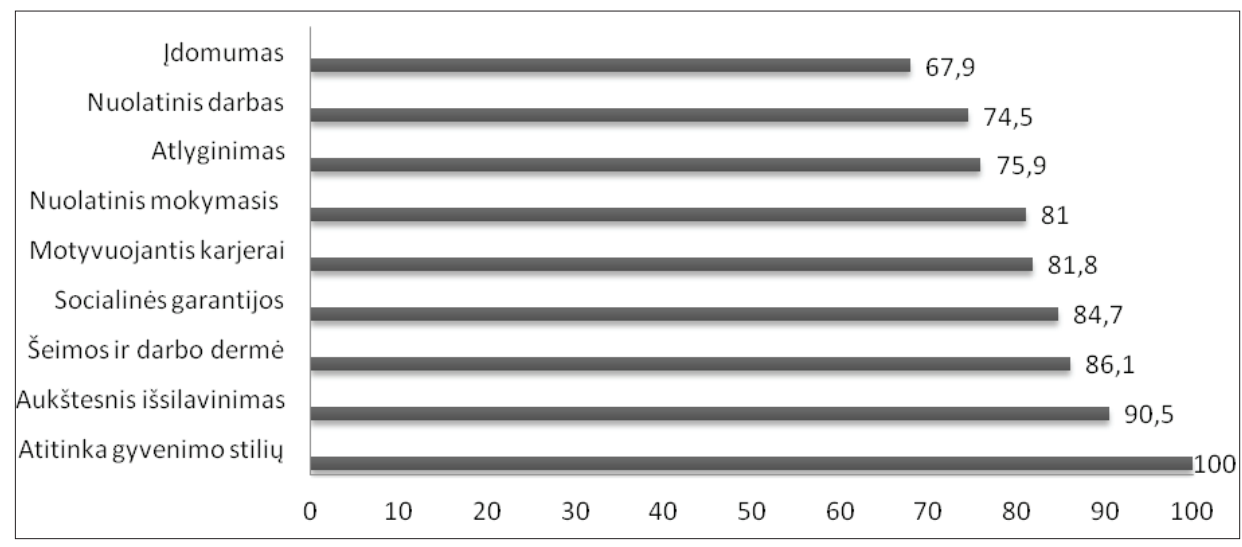

3 pav. Karjeros poreikị formuojančių profesijos pasirinkimo veiksnių analizė

Atliekant tyrimą mėginta nustatyti ne tik teigiamą poveiki karjerai turinčius veiksnius, bet identifikuoti ir pagrindiniai karjeros slopinimo veiksniai, būdingi jūrininko profesijai. Pats didžiausias karjeros slopinimo veiksnys, respondentų nuomone, didelè atsakomybè darbe. Tai rodo, kad jūrininko profesija iš tikrujų didelès atsakomybės reikalaujanti profesija, nepriklausanti nuo turimo jūrinio laipsnio ir laive užimamų pareigų. Kitas labai stiprų slopinamajj poveikị darantis veiksnys didžiulis nuovargis reiso metu: net 83,2 \% respondentu ji îvardijo kaip stipraus poveikio karjerą slopinantị veiksnį. Tokie veiksniai, kaip jūrininko gyvenimo būdo ypatumai ar sunkus darbas, neturi slopinamojo poveikio jūrininko karjerai. Tai patvirtina daugiau nei pusè jūrininkų, tačiau dešimtadaliui pasirinkusiujų jūrinę profesiją šie veiksniai aktualūs (žr. 4 pav.).

Pritaikius $\chi^{2}$ metodą nustatyti statistiškai reikšmingi skirtumai tarp skirtingo amžiaus respondentų ir nuovargio, kaip karjerą slopinančio veiksnio, ịvertinimo, nes $p=0,022<0,05$. Tyrimu nustatyta, kad 70,2 \% respondentų, ịvardijusių nuovargị kaip jūrininko karjerą slopinantị veiksnị, buvo vyresni nei vidutinis respondentų amžius, tai reiškia, kad jūrinių profesijų specialistai karjeros intensyviai turètų siekti iki 39 metų amžiaus, vẻliau šį siekị ima slopinti veiksniai, susiformavę atsakingos profesinės veiklos metu. Pritaikius $\chi^{2}$ metodą nustatyti statistiškai reikšmingi atsakymų skirtumai tarp turimo jūrinio laipsnio ir ịvardytų karjerą 
slopinančių veiksnių: šeimos sukūrimas yra stiprus karjerą slopinantis veiksnys ties 34 arba ties 44 metu riba $(p=0,03<0,05)$; sveikatos būkle yra stiprus slopinantis veiksnys vyresniems kaip 39 metai respondentams; 77,6 \% respondentu, ši veiksnị ịvardijusių kaip karjerą slopinantị veiksnị, buvo vyresni nei 39 metų ( $p=0,040<0,05)$; jürinio gyvenimo ypatumai, kaip karjerą slopinantis veiksnys, ryškus vyresnio amžiaus respondentų grupès atsakymuose: 75,2 \% vyresnių nei 39 metų respondentų minèjo ši veiksni savo anketose $(p=0,020<0,05)$; noras igyti profesija, kaip slopinantis veiksnys, reiškèsi tik jaunesnių, iki 39 metų, respondentų grupejje: 71,3\% ịvardijusių šị karjerą slopinantị veiksnị buvo respondentai iki 39 metu ( $p=0,020<0,05)$; noras tęsti karjera krante yra slopinantis veiksnys, jis reiškèsi vyresnių nei 39 metų respondentų grupeje: 72,3\% respondentų, ši veiksnị ịvardijusių kaip karjerą slopinantị veiksnį, buvo vyresni nei $39 \mathrm{~m}$.

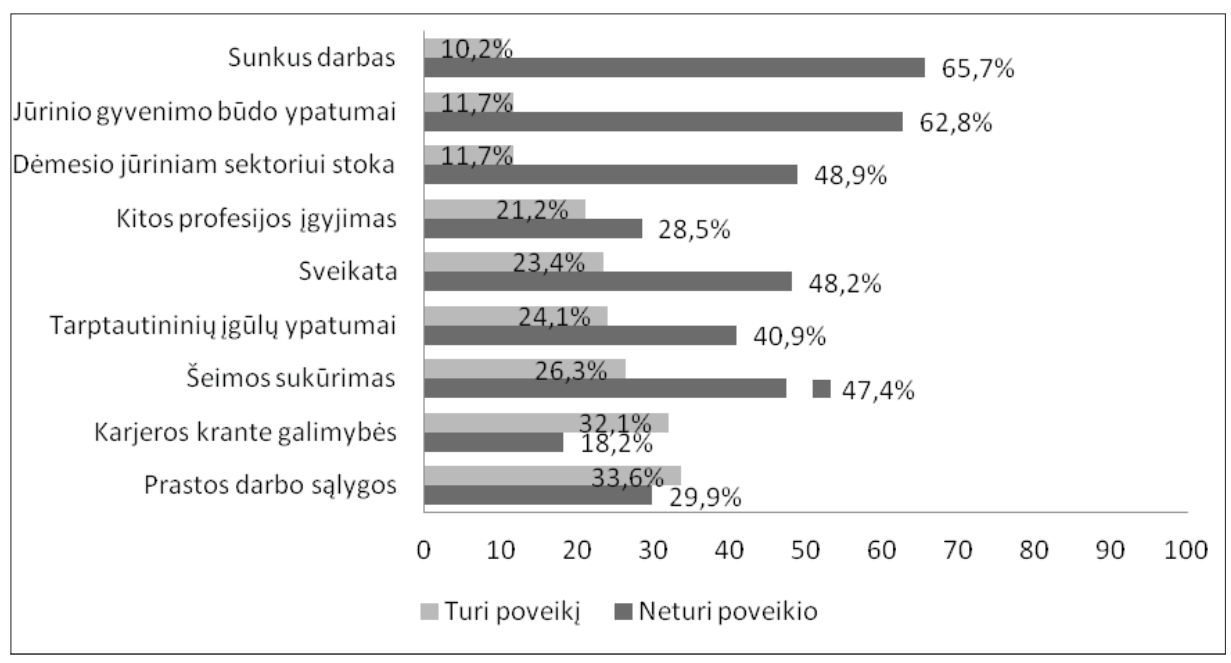

4 pav. Karjerą slopinančių veiksnių poveikio vertinimas

Statistiškai reikšmingų skirtumų, išskyrus aukščiau minètus, vertinant karjerą slopinančius veiksnius tyrimo metu daugiau nenustatyta. Taigi susidaro tokia situacija, kad pradejus veikti karjeros slopinimo veiksniams, esant vyresniems kaip 39 metai, siekti karjeros daug sudetingiau, bet ir atsisakyti profesijos ne taip paprasta, nes ši profesija yra tam tikra jūrininkų saviraiškos priemonè, gyvenimo stilius, todèl psichologiškai keisti profesiją - gana sudètinga. Būtent tokiais rezultatais galima paaiškinti ir tyrimo metu identifikuotą bazinių karjeros siekimo būdų rinkini, kurio pagrindą sudaro ne tik studijos ir kvalifikacijos kèlimas, bet ir asmeninės pastangos siekti papildomų žinių, lavinti igūdžius, nuolatinis domèjimasis jūrine darbo rinka. 


\section{Išvados}

Teorinès analizès pagrindu formuojamos šios išvados:

1. Nustatyta, kad profesija teikia galimybių žmogaus materialiniam apsirūpinimui, sudaro prielaidas ịsitraukti ị visuomeninị gyvenimą, kurti dvasines vertybes, užtikrinti poreikių ir lūkesčių darną. Profesijos pasirinkimą lemia subjektyvieji (vidiniai) ir objektyvieji (išoriniai) veiksniai. Profesijos pasirinkimo atitikimą asmenybei galima vertinti stebint asmens karjerą, kuri apibrēžiama kaip visą gyvenimą besitęsiantis procesas, kai ịgyjama ir tobulinama sẻkmingai karjeros raidai būdinga kompetencija, o karjeros, kaip elementų sekos, supratimas reiškia, kad yra galimybių planuoti ir valdyti karjeros procesą, nuo to priklauso ir karjeros sėkmè.

2. Lietuvoje jūrinių profesijų specialistų rengimą ir diplomavimą reguliuoja nacionaliniai ir tarptautiniai teisès aktai, pasirašomi ir tvirtinami politiniu lygmeniu. Jų igyvendinimą kontroliuoja vykdančiojo lygmens institucijos, o edukaciniu lygmeniu ịgyendina edukacinès, vykdančiojo lygmens institucijų akredituotos mokymo ịstaigos. Kadangi jūrininko profesija yra tarptautinè, tai ir jos teisinis reguliavimas yra mišrus: galioja suderinti teisès aktai, tačiau siekiant aiškiau interpretuoti su jūrininkų teisèmis susijusias problemas, reikia turèti minimalų, tinkamai suderintą ir kontroliuojamą jūrininkų darbo standartą, kuris užtikrintų jūrininkų teisių apsaugą ne tik Lietuvoje, bet ir tarptautinejje erdvejje. Tai teigiamai veiktų jūrinès profesijos karjeros planavimą ir jos siekį. Kaip siekti jūrinès profesijos karjeros, apibrèžia LR susisiekimo ministro patvirtintos taisyklès, kuriose apibrèžti jūriniai laipsniai. Tai palengvina jūrininkų karjeros stebėseną ir sudaro prielaidas planuoti jūrininkų karjerą.

Jūrinių profesijų specialistų apklausos pagrindu formuojamos šios išvados:

1. Tiriant jūrinès profesijos specialistų karjeros projektavimo ir įgyvendinimo veiksnius nustatyta, kad didžiosios dalies jūrininkų profesijos pasirinkimą lėmè subjektyvūs veiksniai: jūrinių profesijų specialistų siekis patenkinti savo interesus, profesija atitiko pomėgius, padejo atskleisti charakterio bruožus. Objektyvių veiksnių poveikis profesijos pasirinkimui buvo daug silpnesnis. Šių specialistų jūrinio laipsnio ir ketinamo ịgyti jūrinio laipsnio analizè atskleidè, kad didžioji dalis respondentų ketina siekti aukštesnio lygio jūrinio laipsnio. Tai būdinga tiek laivavedybos, tiek ir inžinerinius jūrinius laipsnius turintiems jūrininkams. 
2. Egzistuoja tam tikras bazinis subjektyvių ir objektyvių veiksnių rinkinys, kurị ịvardijo visi tyrime dalyvavę jūrininkai: studijos aukštojoje mokykloje, papildomi kvalifikacijos kèlimo ir atestacijai būtini profesiniai kursai, specializuotos konsultacijos, domejjimasis perspektyviausias karjeros galimybes sudarančiais darbdaviais; asmeninès pastangos siekiant tapti aukštos kvalifikacijos specialistu bei asmeninès pastangos turèti žinių.

3. Pagrindiniai karjerą slopinantys veiksniai - didelė atsakomybė darbe ir nuovargis. Karjerą slopinančių subjektyvių ir objektyvių veiksnių analizé atskleidè, kad intensyviau karjeros poreikis formuojasi jaunesniame amžiuje. Jeigu jūrininkams nepasiseka igyti aukštesnio laipsnio, kol jie yra jaunesni, vẻliau stipriau reiškiasi karjerą slopinantys veiksniai ir siekti karjeros vis sudètingiau, tačiau veikiant subjektyviems veiksniams, jos atsisakyti vyresnio amžiaus specialistams taip pat sudètingiau. Todẻl svarbus uždavinys yra karjeros planavimas, ypač jaunesniame amžiuje, nes iš pasirinktos imties jaunesnių jūrininkų gauti duomenys rodo, kad atsiranda papildomas poveikị turintis veiksnys - tai profesijos keitimo grèsmè. Tyrimo rezultatai atskleidè, kad didžiajai daliai jūrininkų, siekiančių karjeros, sudarytos palankios sąlygos, tačiau karjeros plano ịgyvendinimo nesėkmès atveju didžioji jų dalis nežinotų, kaip elgtis. Tokị rezultatą galima paaiškinti tuo, kad planuodami karjerą jaunesnio amžiaus respondentai labiau atsižvelgia ị turimas žinias apie ịsidarbinimo galimybes, studijų tęsimo galimybes ir informacijos apie tai pakankamumą. Taigi planuojant karjerą, objektyvūs veiksniai ypač stipriai veikia vyresnius jūrininkus. Pastebèta, kad ne mažesnị vaidmenị vaidina ir subjektyvūs veiksniai: tobulintinų charakterio savybių pažinimas.

Gauta 20160812

Pasirašyta spaudai 20161015

\section{Literatūra}

Adamonienè, R. (2007). Karjeros projektavimas ir valdymas. Mokomoji knyga. Kaunas: Akademija.

Arnold, J. (2005). Managing careers into the 21st century. London: Paul Chapman Publishing Ltd.

Arnold, J. (2011). 21st century career concepts: Magic, measurement, and career capital. The Psychologist, No. 24, p. 106-109.

Augienè, D. (2009). Karjera: nuo profesijos pasirinkimo iki profesinès veiklos organizacijoje. Studijų knyga. Šiaulių universitetas.

Barkauskaitè, M. (2007). Profesinis konsultavimas ir orientavimas šiuolaikinio profesinio rengimo kontekste. Acta Paedagogica Vilnensia, T. 18, p. 106-120. Vilnius.

Danilevičius, E. (2008). Karjeros projektavimo ir karjeros planavimo ugdymo edukologinès prielaidos. Pedagogika, Nr. 92, p. 110-115.

Dries, N., Pepermans, R., Carlier, O. (2008). Career success: Constructing a multidimensional model. Journal of Vocational Behavior, Vol. 73, No. 2, p. 254-267. 


\section{Diana Saveikienè}

Eder, F., Hörn, G. (2013). Konsultavimo karjerai testai būsimiems mokytojams. Karjeros projektavimas: tyrimai ir konsultavimas, Nr. 2. Zalcburgo universitetas.

Germeijs, V., Verschueren, K. (2007). High school students' career decision-making process: Consequences for choice implementation in higher education. Journal of Vocational Behavior, Vol. 70(2), p. 223-241.

Yaxley, H. M. L. (2012). Exploring the origins of careers in public relations. Public Relations Review, Vol. 38 (3), p. 399-407.

Yaxley, H. M. L. (2013). Career experiences of women in British public relations (1970-1989). Public Relations Review.

Jovaiša, L. (2007). Enciklopedinis edukologijos žodynas. Vilnius: Gimtasis žodis.

Jovaiša, L. (2009a). Gyvenimo sèkmés ugdymas. Vilnius: Agora.

Jovaiša, L. (2009b). Profesinio orientavimo ir konsultavimo psichologija. Vilnius: Agora.

Jovaiša, L. (2011). Edukologija, T. 1. Vilnius: Agora.

Jovaiša, L. (2012). Edukologija, T. 2. Vilnius: Agora.

Jovaiša, R. T. (2012). Profesinès veiklos tyrimas. Vilnius: Edukologija.

Kalvaitienė, G. (2010). Jūreivystės studentų profesinės karjeros savivaldos gebejjimų ugdymo prielaidos. Profesinis rengimas: tyrimai ir realijos, Nr. 19, p. 60-71.

Kalvaitienè, G. (2012). Jüreivystès studentu profesinès karjeros planavimo mokèjimu ugdymo modelis. Daktaro disertacija. VDU.

Kavaliauskienė, V. (2011). Pažintis su profesija. Klaipėdos universiteto leidykla.

Laužackas, R. (2005a). Profesinio rengimo metodologija. Kaunas: VDU.

Laužackas, R. (2005b). Profesinio rengimo terminų aiškinamasis žodynas. Kaunas: Vytauto Didžiojo universitetas.

Lietuvos pažangos strategija ,Lietuva 2030“. (2012).

Lietuvos Respublikos jūrininko knygelès išdavimo ir užpildymo taisyklès. (2006). Valstybès žinios, Nr. 22-720.

Lietuvos Respublikos jūrinio laipsnio diplomų ir kvalifikacijos liudijimų jūrininkams, plaukiojantiems tarptautiniais reisais, išdavimo taisyklès. (2005). Valstybès žinios, Nr. 99-3725; (2006). Valstybès žinios, Nr. 77-3025.

Lietuvos Respublikos susisiekimo ministro 2001 m. balandžio 9 d. ịsakymas Nr. 110 „Dèl mokymo įstaigų, suteikiančių asmenims teorinị ir praktinị pasirengimą, būtiną jūrinio laipsnio diplomui, kvalifikacijos liudijimui ar jų patvirtinimui gauti, akreditavimo nuostatų patvirtinimo“(2001). Valstybès žinios, Nr. 32-1085; (2011). Valstybès žinios, Nr. 165-7880.

Navickienè, L. (2012). Karjeros konsultanto kvalifikacijos parametrai. Karjeros projektavimas: tyrimai ir konsultavimas, Nr. 1. Kaunas: Vytauto Didžiojo universitetas.

Petkevičiūtè, N. (2006). Karjeros valdymas: asmeninè (individualioji) perspektyva. Mokomoji knyga. Kaunas: Vytauto Didžiojo universiteto leidykla.

Plant, P. (2012). Akivaizdu? Kokybės užtikrinimas ir įrodymais grindžiamas karjeros projektavimas Europoje: kritinė apžvalga. Karjeros projektavimas: tyrimai ir konsultavimas, Nr. 1. Aarhus universitetas.

Pukelis, K. (2012). Karjeros projektavimas: kodėl ir kas? Karjeros projektavimas: tyrimai ir konsultavimas, Nr. 1. Kaunas: Vytauto Didžiojo universitetas.

Pukelis, K. ir kt. (2007). Profesinio konsultavimo metodinès rekomendacijos profesijos konsultantams. Kaunas: VDU.

Pukelis, K. (2009). Gebėjimas, kompetencija, mokymosi / studijų rezultatas, kvalifikacija ir kompetentingumas: teorinè dimensija. Aukštojo mokslo kokybe, Nr. 6, p. 12-35.

Pukelis, K., Navickienè, L. (2010). Training of career counsellors: needs, issues and perspectives. Pedagogika: mokslo darbai, Nr. 97, p. 50-59. Vilniaus pedagoginio universiteto leidykla.

Pukelis, K., Navickienė, L. (2011). Karjeros konsultantų profesijos problema. Profesinis rengimas: tyrimai ir realijos, Nr. 20, p. 116-133. Kaunas: Vytauto Didžiojo universiteto leidykla.

Rosinaite, V. (2010). Karjeros sampratos konstravimas Lietuvoje. Daktaro disertacija. Vilnius: Vilniaus universitetas.

Ruppert, J. J., Ertelt, B. J. (2013). Emancipuojamasis profesinio vadovavimo modelis. Karjeros projektavimas: tyrimai ir konsultavimas, Nr. 2. Mannheim universitetas.

Sultana, R. (2012). Kokybės klausimai: aukštų standartų užtikrinimas teikiant karjeros projektavimo paslaugas. Karjeros projektavimas: tyrimai ir konsultavimas, Nr. 1. Aarhus universitetas.

Saugios laivybos įstatymas. (2000). Valstybès žinios, Nr. 75-2264. 
Savickas, M. L. (2005). The Theory and Practice of Career Construction. In S. D. Brown, R. W. Lent (eds.). Career Dvelopment and Counseling. Putting Theory and Research to Work. New Jersey: John Wiley \& Sons.

Savickas, M. L. (2012). A Paradigm for Career Intervention in the 21 st Century. Journal of Counselling \& Development, January, Vol. 90, p. 13-19.

Sokolova, A., Stanišauskienė, V. (2007). Profesinio orientavimo sistemos Lietuvoje teorinès ir politinès prielaidos. Profesinis rengimas: tyrimai ir realijos. Vilnius.

Tijūnėlienė, O., Kavaliauskienè, V. (2008). Antano Maceinos ugdytinio veiklumo koncepcijos interpretacija asmenybès savikūros požiūriu. Acta paedagogica Vilnensia, T. 21, p. 41-51.

Tūtlys, V. (2013). Karjeros projektavimo ir profesinio rengimo sąveika Lietuvoje: galimybių spąstų problemos sprendimas. Karjeros projektavimas: tyrimai ir konsultavimas, Nr. 2. Kaunas: Vytauto Didžiojo universitetas.

Urbanavičiūtè, I. (2010). Profesinio kelio rinkimosi vidiniai ir išoriniai veiksniai. Daktaro disertacija. Vilnius: Vilniaus universitetas.

Vinkenburg, C. J., Weber, T. (2012). Managerial career patterns: A review of the empirical evidence. Journal of Vocational Behavior, Vol. 80, Issue 3, p. 592-607.

Wilensky, H. L. (1961). Careers, lifestyles, and social integration. International Social Science Journal, Vol. 12(4), p. 553-558.

\section{THE FACTORS OF MARITIME PROFESSIONALS CAREER DESIGNING AND IMPLEMENTATION}

\section{Diana Saveikienè}

\section{Summary}

The labour market of maritime professionals is characterized by extreme changes in the workplace and legal regulations. This urges to conduct the research of factors of career development and implementation of maritime professionals. The aim of this article is to analyse the factors of design and implementation of further career of marine professionals and to reveal the theoretical fundamentals of career design and implementation factors, to highlight the assumptions which the Lithuanian Seafarer's Training and Certification System and the legal framework provide for career planning and implementation and to identify the factors of career designing and implementing of maritime professionals.

The relevance of the study is based on the fact that vocational information and counselling, and individual career development are important tasks of the education system and the important elements of the strategy of lifelong learning and is a priority document of the European Commission: Memorandum on Lifelong Learning (2001). The chosen research problem responds to the Lifelong Learning Strategy (15 October 2008, No ISAK-2795 / A1-347) updating the idea provided in the Communication on Adult Learning: It is never too late to learn. The 
relevance of the chosen research problem is based on the order of the Minister of Education and Science of the Republic of Lithuania and the Minister of Social Security and Labour of the Republic of Lithuania on approval of the description of the procedure for the implementation of vocational guidance (2012). It states that the goal of vocational guidance is to help individuals to make a deliberate choice of adequate education and employment opportunities, to enable the acquisition of career competency, and to develop their careers (i.e. the lifelong sequence of learning, self-expression and the work experience of the person significant to individual and society).

The empirical study was carried out in March-April 2014. Maritime professionals who acquired the specialty under the study programme of the Marine navigation or Operation of marine energy equipment at the Faculty of Marine Technology of Klaipeda University of Lithuania or Lithuanian Maritime Academy represented the population of subjects. A non-probability purposive sampling method was used for the conclusion of the study sample: marine professionals who planed to participate in training courses were selected. The quantitative study using a questionnaire survey was carried out to implement the objective of this study. The study sought to survey 137 maritime professionals.

While analysing the theoretical framework of the career design and implementation of marine professionals, it has been established that occupation provides opportunities for human material security, creates preconditions to engage in public life, develops spiritual values, and ensures the consistency between needs and expectations. Satisfaction in the chosen profession depends on the personality traits and other factors characterizing the two main types of personal expectations one of which is matching of a profession to the imaginative ideal profession, and the other - matching of a profession considered to be the prestigious profession by the public. The choice of profession is determined by subjective (inner) and objective (external) factors. Subjective factors ensure the processes of freedom of self-expression and development of a person whereas objective factors define person's involvement in public activities and justify his relationship with other individuals. That's why in particular in investigating the choice of profession it is necessary to analyse both subjective and objective factors influencing the choice of profession. Professional suitability can be assessed by monitoring personal career, which is defined as a life-long process when the competence characteristic to the development of a successful career is acquired and developed. The understanding of a career as a sequence of elements means that there are opportunities to plan and manage the career process and that career success depends on it.

National and international legislation signed and approved at the political level regulates the training and certification of marine professionals in Lithuania. 
Their implementation is controlled by the executive-level institutions, and at the educational level they are implemented by educational training institutions accredited by the executive-level institutions. As a seafarer profession is international, its legal regulation is mixed and the harmonised legislation is in force. However, in order to interpret more clearly the problems associated with seafarers' rights, the minimum and properly aligned and controlled seafarers working standard is needed to ensure the protection of the seafarers' rights not only in Lithuania, but in the international environment as well, which would have a positive impact on the career planning and implementation of marine professionals. Ways of achieving a maritime profession define the rules issued by the Minister of Transport and Communications of the Republic of Lithuania for seafarers' degrees which facilitate the monitoring of seafarers' careers and create preconditions for planning of seafarers' careers.

Factors of career design and implementation of the maritime professionals. During the examination of the factors of career design and implementation of maritime professionals, it was found that the seafarers' profession was mostly chosen due to subjective factors, e.g. marine professionals wanted to satisfy their interests, the profession was in line with the person's hobbies, and the seafarers' profession helped to reveal their character traits. The impact of objective factors on the choice of profession was considerably weaker. The analysis of the professionals' degree showed that the majority of respondents intended to achieve a higher level of marine degree. This was typical to both the seafarers' with the degrees in marine navigation and in marine engineering; however, those with the lowest degree sought to gain a few levels higher maritime degrees, and it was more specific to younger respondents.

Certain basic subjective and objective factors were identified by all seafarers who participated in the study, namely such factors as studies in higher education institutions, additional professional training courses and courses required for certification purposes, specialized advice, interest in promising employers providing career possibilities can be distinguished from objective factors, and from the subjective factors - personal efforts to become a highly skilled professional and personal efforts to gain knowledge.

The main factors inhibiting career are a big responsibility at work and fatigue. The analysis of subjective and objective factors inhibiting career showed that a more intense need for career was formed at a younger age. If mariners failed to gain a higher degree at a younger age, then the factors that inhibit career had stronger impact and the pursuit of career became more difficult. On the other hand, it is more complicated for older professionals to refuse career later under the impact of subjective factors. Therefore, a very important task is career planning, especially 
at a younger age, because the data obtained from selected younger sailors showed that there appeared an additional factor, namely a threat to change the profession. The study results showed that the majority of seafarers pursuing a career had favourable conditions, but in case of failure of implementing a career plan, the majority of them would not know what to do. This result can be explained by the fact that younger respondents in planning their career took into account the available opportunities for employment, opportunities for continuation of studies and the adequacy of information about it. Thus, in career planning the objective factors particularly affect older sailors. It was observed that subjective factors such as cognition of personality traits to be improved also played an important role.

It may be concluded that seafarers who are planning a career lack skills in career planning, so there is a need to include a career planning module in the seafarers training and retraining or certification programs. 